\title{
A SMART KEZDEMÉNYEZÉSEK ALKALMAZHATÓSÁGÁNAK VIZSGÁLATA MAGYARORSZÁGON
}

ANALYSIS OF THE APPLICABILITY OF SMART INITIATIVES IN HUNGARY

\section{Némediné Kollár Kitti PhD', Káposzta József CSc², Péli László PhD}

\author{
${ }^{1}$ adjunktus, ${ }^{2,3}$ egyetemi docens, \\ ${ }^{1,2,3}$ Szent István Egyetem, Gazdaság- és Társadalomtudományi Kar, Regionális Gazdaságtani \\ és Vidékfejlesztési Intézet \\ E-mail: ${ }^{1}$ kollar.kitti@gtk.szie.hu, ${ }^{2}$ kaposzta.jozsef@gtk.szie.hu, ${ }^{3}$ peli.laszlo@gtk.szie.hu
}

\section{Összefoglalás}

Az évről évre megjelenő hazai és nemzetközi szakirodalmak, illetve a számos SMART témakörben készülő publikáció is igazolja azt a tényt, hogy napjainkban a területfejlesztés egyre nagyobb figyelmet fordít az innováció feltételeinek és hatásainak vizsgálatára. Az elmúlt két évtizedben az Európai Unió is újraértékelte az innovációs politikáját, amelynek hatására új eszközök és módszerek jelentek meg a SMART tényezőkhöz kapcsolódóan. Továbbá fontos kiemelnünk, hogy napjaink területi folyamatai egyre inkább azt mutatják, hogy a városias (urbánus) jellegű területek szerepe felértékelődik, hiszen a városi jellegü területek a gazdasági növekedés motorjai (Káposzta et al., 2016). Ha a Föld egészét tekintjük, akkor elmondható, hogy a városlakók aránya 2017-ben meghaladja a Föld jelenlegi népességének felét, amely arány (előzetes becslések alapján) a jövőt tekintve feltehetően emelkedni fog. Az Európai Unió SMART City koncepciója a városok versenyképességét az ott élhető élet minőségét és az ebben szerepet játszó társadalmi-, gazdasági-, és környezeti infrastruktúra javítását célozza meg elsődlegesen, kiegészülve az elérhető szolgáltatások mennyiségével és minőségével. Jelen tanulmány célja, hogy áttekintést adjon a hazai SMART kezdeményezések jelenlegi helyzetéröl.

\begin{abstract}
Annually the domestic and international literature published a series of SMART themes illustrate the fact that today's spatial and rural development is increasingly focusing on examining the conditions and impacts of innovation. Over the past two decades, the European Union has re-evaluated its innovation policy, with new tools and methods emerging in relation to the SMART factors. In terms of the Earth as a whole, the proportion of urban inhabitants exceeds half of the current population of the Earth, which proportion is likely to rise (based on preliminary estimates) in the future. The spatial processes of the European Union and Hungary both show that the role of urban (urban) areas is appreciated, as urban areas provide the engine of economic growth (Káposzta et al., 2016). The SMART City concept of the European Union aims at improving the quality of life and the social, economic and environmental infrastructure in this area, complemented by the quantity and quality of services available. The primary task of the European Union SMART Village concept is to increase the country's population retention power. The purpose of this paper is to provide an overview of the current state of the SMART initiatives in Hungary.
\end{abstract}

Kulcsszavak: SMART City kezdeményezések, SMART Village, élhetőbb város, IKT

JEL kód: R10, R11

LCC kód: H1-99 


\section{Bevezetés}

A területfejlesztéssel foglalkozó szakemberek teljes mértékben egyet értenek azzal a ténnyel, hogy a jövő legfőbb gazdasági tényezői a városok. Az urbanizációra és a környezeti változásokra reagálni kell és lehetőségeinket kihasználva lépést tartani a fejlődéssel, mely folyamatban egyre nagyobb részt vállalnak a piaci szereplők és maguk a városlakók is (KassaiMolnár, 2016). 1990-es évek közepén jelent meg elöször az okos város fogalma elsősorban a fenntartható növekedéshez, másrészt a városirányítás megreformálásához kapcsolódóan. Megjelentek az infó-kommunikációs technológiák, amelyek eleinte a vállalkozásoknak kínáltak alapvető szolgáltatásokat, majd a későbbekben már megjelentek a közmüvek és a közlekedés is. Négy föszereplőt különböztetünk meg az innovációs környezetben: a kormányzati szférát, az üzleti szférát, az oktatási közösséget illetve a civil szférát (TóthKáposzta, 2014).

Az innovációs környezet és az innovációs rendszer azoknak a tudás előállító, terjesztő és felhasználó intézményeknek a köre, amelyek külön-külön és együttesen hozzájárulnak az új technológiák fejlesztéséhez és elterjedéséhez. Az egyes intézmények képességei és a köztük lévő kapcsolatrendszer határozzák meg egy nemzet, egy régió, egy terület vállalatainak innovatív gazdasági teljesítményét. Ezek az intézmények adják annak a keretét, amelyen belül a kormányzatok kialakítják és megvalósítják az innovációs folyamat előmozdítása érdekében folytatott politikájukat. A kölcsönös kapcsolatban müködő intézmények rendszere elősegíti az új technológiát meghatározó új tudás, új képességek és új termékek előállítását, megőrzését és átadását (Vas-Bajmóczy, 2012).

A jövő városai megjelenésükben valószínűleg nem fognak jelentősen eltérni a jelenlegi állapotuktól, azonban a SMART City koncepciók értelmében eltérő lesz a bennük müködő rendszerek és szolgáltatások minősége és ezeken keresztül közvetett hatásként a várost használó emberek életminősége is (Lados, 2011; Káposzta et al., 2016). 2017-ben elmondható, hogy ezen folyamatok elején tartunk, hiszen az Európai Uniónak jelenleg is kialakulóban van a SMART City és az ezzel párhuzamos SMART Village koncepciók átfogó szabályozása. Azonban fontos kiemelni, hogy kardinális figyelmet kapnak a támogatás és pályázás szempontjából az alábbi kormányzási célok mint az energiahatékonyság, az erőforrásgazdálkodás, illetve a gazdasági versenyképesség. Az okos város projektek önkormányzat irányításával és felügyeletével, városi kezdeményezéseken és jellemzően állami vagy Európai Uniós forrásokból valósulnak meg. Mind a világ, mind pedig a hazai térgazdasági folyamatokat vizsgálva megállapítható, hogy a fejlett világban gyökeres szemléletváltás történt a városfejlesztési politikák kialakítása terén (McLaren et al., 2015). Ezt támasztja alá az a tény is, hogy az Európai Unió szinte összes tagállama napirendre vette a SMART City projektek elindítását, városaik átalakítását úgy, hogy azok képesek legyenek hatékonyan integrálni és alkalmazni a legújabb technológiákat, miközben megfelelnek a kor elvárásainak is. Fontos prioritásként szerepel, hogy a városban élő polgárokat bevonják a döntéshozatali folyamatba, a szolgáltatásokat összekötik egymással és az így keletkező adatvagyont újra felhasználhatóvá teszik (www.hvg.hu). Az Európai Unió térségében is egyre több példát láthatunk arra, hogy egy város következetesen és részletesen kidolgozott SMART City, esetleg SMART Village koncepcióval rendelkezik. Véleményünk szerint az ezen irányú pályázati források számának és mértékének prognosztizált növekedése a tagországokat pozitív irányba ösztönzi majd a SMART koncepciók terén a jövőt tekintve.

\section{Anyag és módszer}

A tanulmányban dokumentumelemzés és szakirodalmi feldolgozás módszerét alkalmazzuk, amely segítségével összeállítjuk az okos városokhoz, az okos falvakhoz kapcsolódó és azok 
jelenlegi koncepcióját megalapozó külföldi és hazai szakirodalmakat, beleértve a hazai jogszabályi háttér ismertetését, az infokommunikációs technológiákat alkalmazó városfejlesztési folyamatot, illetve az okos város fejlesztési modell föbb összefüggéseit. A tanulmány alapját egy 2017 szeptemberében indított kutatás adja, melyet a Szent István Egyetem gazdasági és vidékfejlesztési agrármérnök (BSc) hallgatóinak bevonásával valósítunk meg. További célunk a jövőben a hazai „zászlóshajó” SMART kezdeményezések vizsgálata, melyhez jelen tanulmány alapul szolgál.

\section{SMART Village, City}

\section{Az infokommunikációs forradalom városokra gyakorolt hatása}

A XXI. században az infokommunikációs technológiára alapuló megoldások hozzáférhetősége világszerte exponenciálisan nő, beleértve a telekommunikációt, az információs technológiát (IT) és az elektronikus szolgáltatásokat (e-szolgáltatások). Ezek az eszközök, a kezdeti, vonalas majd mobiltelefon-hálózaton müködő szolgáltatásoktól a későbbi, internetes multimédiaalkalmazásokig, óriási társadalmi és gazdasági hatással jártak. Az IKT hálózatok fejlődése és terjedése új gazdasági és társadalmi lehetőségeket teremt. Azáltal, hogy olyan platformot képez, amelyhez csatlakozva vállalkozások, kormányzati szereplők és állampolgárok kommunikálhatnak, bekapcsolódhatnak különböző üzleti és társadalmi folyamatokba, folyamatosan át is formálja az üzleti és társadalmi kapcsolatteremtés, kapcsolattartás módját. Továbbá elmondható, hogy összeköt elkülönülő piacokat, egyéneket, globális kommunikációs lehetőségeket teremt, ezáltal teremtve új, emelve a jövedelmeket, ösztönözve a kereskedelmi kapcsolatokat és csökkentve a távolsági és időbeli korlátok leküzdésének költségeit (Lados, 2011; Biocon Tanácsadó Bt., 2016).

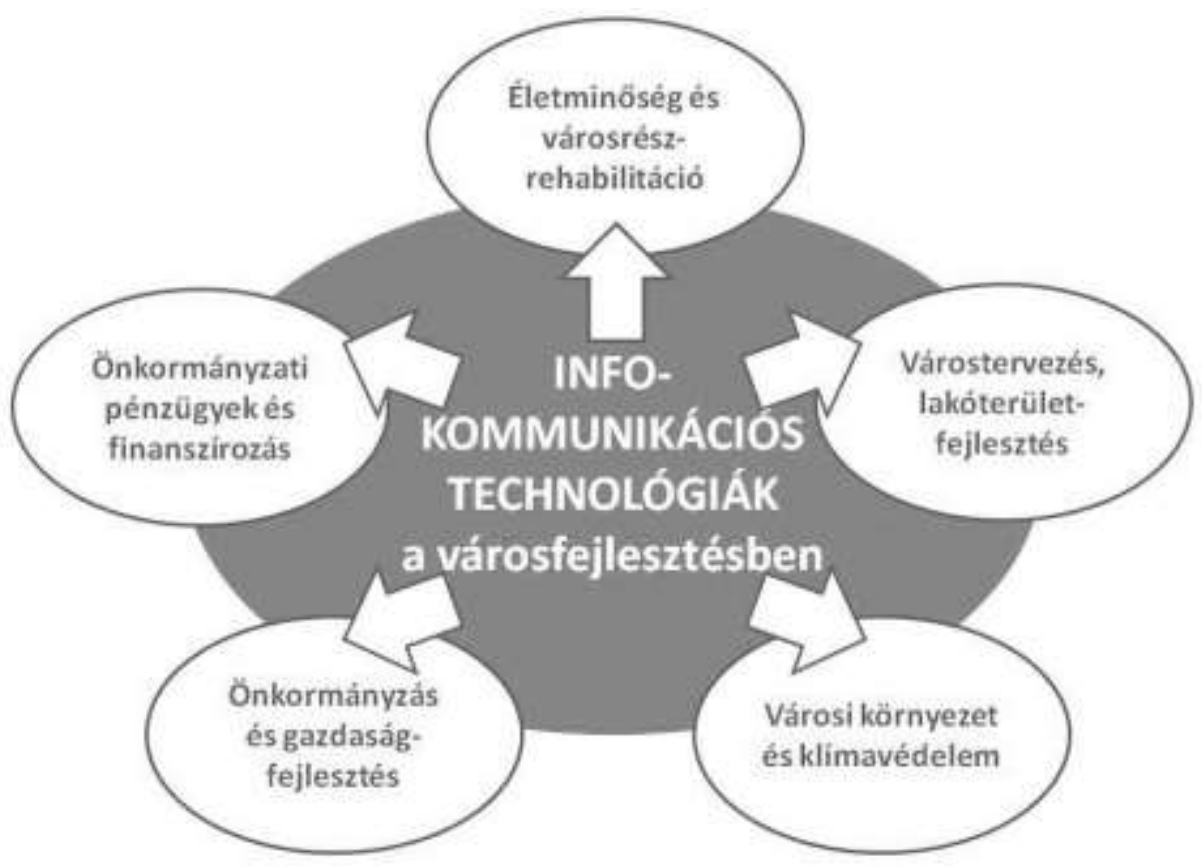

1. ábra: Infokommunikációs technológiák a városfejlesztésben

Forrás: Biocon Tanácsadó Bt. alapján saját szerkesztés, 2017.

Az IKT szektor fejlődése nyomán a XXI. században globális urbanizációs folyamatok zajlanak majd le és a városok az adott ország vagy régió egyre fontosabb szereplőivé válnak. A folyamatban lévő infokommunikációs forradalom olyan mértékben alakítja majd át a városokat, változtatja meg társadalmi és gazdasági berendezkedésüket és rendezi át 
erősorrendjüket, mint tette azt az ipari forradalom az akkori mezőgazdasági jellegü városokkal világszerte. A jövő gazdaságilag sikeres és vonzó életkörülményeket biztosító városai éppen azok, akik a jelenben minél nagyobb teret engednek az új információs és telekommunikációs technológiai megoldásoknak (Batty M. et al., 2012 ; Biocon Tanácsadó Bt., 2016).

Fontos kiemelni, hogy a fentiekben már említett infokommunikációs eszközök és szolgáltatások a modern városfejlesztésben közvetett és közvetlen módon egyértelmüen kedvező hatást gyakorolnak a gazdasági növekedésre, a foglalkoztatottságra, az életminőségre, a vállalkozások hatékonyságára és versenyképességére, illetve az esélyegyenlőségre. Az 1 . sz. ábrán az IKT központi szerepét mutatjuk be a városfejlesztésben. Az alábbiakban azon áttételes hatásokat gyüjtöttük össze, amelyek a lakosság életminőségét és esélyegyenlőségét is érdemben javítják (http://kozigazgatas.netenahivatal.gov.hu):

- Fogyasztói jólét: nagyobb választék, alacsonyabb árak, jobb fogyasztói informáltság (pl. ár-összehasonlító szolgáltatások), több értékesítési csatorna, új szolgáltatások (pl. közösségi portálok, tudástárak) elérhetősége.

- Foglakoztatás: távmunka, atipikus foglalkoztatási formák, online álláskeresés, egyszerübb önfoglalkoztatás, a képzésekkel és munkahelyekkel kapcsolatos információk egyszerü elérhetősége, új munkahelyek az IKT-szektorban, online trainingek, csoportmunka, coaching.

- Üzleti környezet: új üzleti modellek; e-kereskedelem, e-bankolás, új kereskedelmi partnerek felkutatásának lehetősége, közvetítők kiiktatása, új értékesítési csatornák.

- Vállalati teljesítmény: költségcsökkentés, hatékonyságnövelés (pl. távmunka, outsourcing), egyszerübb kommunikáció a partnerekkel, információk gyorsabb és egyszerübb megszerzése, új értékesítési csatornák, folyamatok informatizálása, élőmunka kiváltása.

- Környezetvédelem: intelligens áramellátás és fogyasztásmérők (smart grid), felhőalapú szolgáltatások, távmunka, ,okosházak”, intelligens városfejlesztés (SMART City), monitoring /távfelügyelő rendszerek.

- Oktatás és kutatás: oktatás-adminisztráció informatikai támogatása, e-oktatás, online tananyagok, e-learning, egész életen át tartó tanulás.

- Egészségügy: e-egészségügyi alkalmazások, monitoring rendszerek, távdiagnosztika, az orvoslátogatások számának csökkenése, kutatás-fejlesztés, egészségügyi információs és kutatói adatbázisok létrehozása (http://kozigazgatas.netenahivatal.gov.hu).

\section{SMART City fogalmi lehatárolás}

Általánosságban elmondható, hogy az okos város, avagy SMART City olyan gyüjtőfogalom, amely lényege, hogy a fejlesztéseket a helyi igényekhez kell igazítani, ennek első lépése a települési stratégiák kialakítása. Az angol nyelvü „SMART City” elnevezést fordíthatjuk „korszerü” „emberközpontú”, de talán a leginkább ismert „élhető város” fordítás. Egy várost akkor nevezünk okosnak, ha fenntartható gazdasági fejlődését a hagyományos és digitális infrastruktúrába, humán és társadalmi tőkébe való kiegyensúlyozott befektetés révén, az érintett közösség érdekeltjeinek bevonásával, annak részvételével, környezettudatos módon éri el. Okos városnak lenni egy folyamat, a folyamatos fejlesztés útja. Az okos város nélkülözhetetlen részei az "okos városlakók", ez alapvető feltétele egy város fejlődésének (Dobos et al., 2015). Azok a városok sikeresek, ahol teret engedtek az innovációs tevékenységnek, amihez az önkormányzatok részéről szolgáltató szemlélet szükséges. Fontosnak tartjuk, hogy a kényelmi szolgáltatások találkozzanak a valós igényekkel. Ehhez először a beruházóknak kell megérteniük, hogy miként müködik az adott terület, és ehhez a helyzethez kell igazítaniuk az okos várost szolgáló fejlesztéseket. Az Okos Városok Kézikönyve alapján az Okos városok / SMART City egy olyan közeg, ahol a technológiai és az intelligens szolgáltatási megoldások 
komplexebb, életminőségről, hatékonyságról, ökológiai és gazdasági fenntarthatóságról szóló célok eszközei. Ezek más eszközökkel együtt alkalmazva tudnak sikeresen müködni: a szolgáltatások minőségének és hatékonyságának javítása érdekében, az energia és más erőforrások takarékosabb felhasználása érdekében, illetve az állampolgárok bevonása és az életminőség javításának érdekében (Dobos et al, 2015).

Jelenleg 2017-ben hazánkban a városok száma 328 és a népesség 17,4 \%-a Budapesten, 52, $1 \%$-a a többi városban él (TeIR, 2017). Mint az már a fentiekben is említésre került, a városok a növekedés alapvető motorjai, amely alapján elmondható, hogy a müszaki-, intézményi-, társadalmi-, gazdasági és környezeti infrastruktúra folyamatos fejlesztést igényel. Mindezen tényezőkön kívül a városi élet javításában fontos szerepet töltenek be a beruházások. Miután az Európai Unióban megfogalmazódott a SMART City koncepció igénye, a hazai területfejlesztési politikában is mozgolódások történtek a hazai koncepciók kidolgozása kapcsán. A SMART City koncepció hazai vonatkozásában az első ilyen kormányhatározat 2014-ben jelent meg, a 1631/2014 (XI.6.) Kormány határozata a Digitális Nemzet Fejlesztési Program megvalósításáról, melyben kijelölik az infokommunikációs szektor fejlesztési irányait, céljait, illetve a Nemzeti Infokommunikációs Stratégia végrehajtásának négy pillérét: digitális kompetenciák, digitális gazdaság, digitális infrastruktúra, digitális állam. Majd ezt követően a 2015-ös évben a Magyar Közlönyben megjelent Digitális Nemzet Fejlesztési Program megvalósításával kapcsolatos aktuális feladatokról, valamint egyes kapcsolódó kormányhatározatok módosításáról szóló 1486/2015. (VII. 21.) kormányhatározat 3. pontja a Lechner Tudásközpontot közremüködő félként jelöli meg az intelligens városi szolgáltatások összehangolt bevezetését és működését támogató szervezeti és tudásplatform létrehozásában és müködtetésében, beleértve ebbe az ezekre a szolgáltatásokra vonatkozó ajánlások kidolgozását, valamint a rendszer müködésének monitoringját is. Ezt követően fontos megemlíteni a 2017. március 20-i Magyar Közlönyben megjelent az 56/2017. (III. 20.) Korm. rendeletet, amely az egyes kormányrendeleteknek az „okos város”, „okos város módszertan” fogalom meghatározásával összefüggő módosításáról szól.

Hosszú idő után a kormányrendelet hivatalos keretek között is meghatározza mit értünk okos város alatt: Az okos város olyan település vagy település csoport, amely természeti és épített környezetét, digitális infrastruktúráját, valamint a területén elérhető szolgáltatások minőségét és gazdasági hatékonyságát korszerü és innovativ információtechnológiák alkalmazásával, fenntartható módon, lakosainak fokozott bevonásával fejleszti (56/2017. (III. 20.) Korm. rendelet). A módszertan szerint véghezvitt, fenntartható városfejlesztés horizontális szempontokat - magas minőség és hatékonyság, környezeti és gazdasági fenntarthatóság, lakosság fokozott bevonása - érvényesít a szolgáltatások és az infrastruktúra fejlesztésében egyaránt. A fejlesztés és működtetés eszköztárába integrált információtechnológiák ezek eléréséhez és a fejlődés nyomon követéséhez nyújtanak majd segítséget.

Véleményünk alapján gazdaságilag fenntartható, illetve jól müködő SMART City koncepciót építeni nem könnyü feladat. Minden város speciális belső adottságokkal rendelkezik, ezért nem lehet egy az Európai Unió más városában már bevált SMART koncepciót bármely városra alkalmazni. Így ebből fakadóan speciális belső adottságokra épülő SMART City koncepciót kellene kidolgoznia minden magyar városnak az alábbiak alapján: erőforrás felmérés, következetes és koncepciózus okos város terv készítése. 2014 óta az Európai Uniós tagállamokban és hazánkban is a városértékelések terén számos kutatás foglalkozott és jelenleg is foglalkozik az okos városok értékelésének alkotóelemeivel, illetve módszertanával. A fentiekben már említett kormányhatározat alapján hazánkban a Lechner Tudásközpontot bízták meg a városértékelési monitoring rendszer kidolgozásával. Számos variáció született a monitoring rendszer kidolgozására, azonban az alábbi hat fócsoportot alakították ki a városok helyzetértékelése kapcsán . Ezen stratégiai dokumentumok kialakításában figyelembe vették, 
átdolgozták a brit Smart City szabványt, az EU Smart City Ranking és a Smart Cities Council modelljét, illetve az ISO szabványt is (Nagy et al.,2015):

1. Okos mobilitás, 2. Okos környezet, 3. Okos emberek, 4. Okos életkörülmények, életminőség, 5. Okos kormányzás, 6. Okos, fenntartható gazdaság.

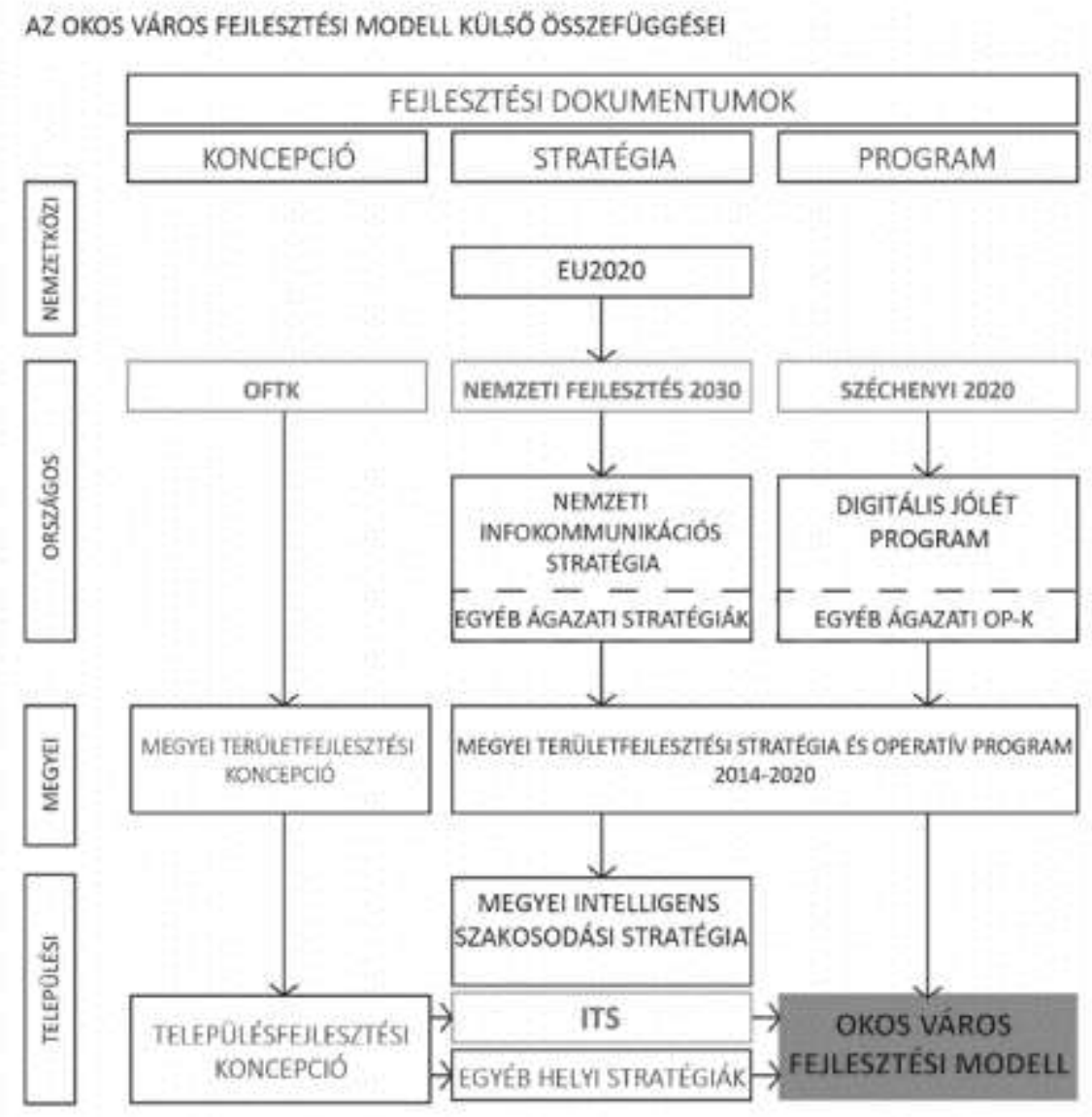

\section{2. ábra: Az okos városfejlesztési modell folyamatábrája}

Forrás: Lechner Tudásközpont alapján saját szerkesztés, 2017.

A 2. ábráról is jól leolvasható, hogy a fejlesztési modell kidolgozása települési szinten történik, amelyet a felsőbb területi szintekről az ITS, a megyei területfejlesztési stratégia és operatív program, a Nemzeti Infokommunikációs Stratégia, a Digitális Jólét Program és az EU2020 stratégiai irányelvei is befolyásolnak. Az Okos városfejlesztési modell megalkotásához nagyon sokféle adattípust gyüjtenek be a városról, amelyből a szakemberek véleménye alapján óriási adatvagyon keletkezik. Általános irányelv, hogy a folyamat során összegyüjtött adatokat megosztják a polgárokkal különböző nyitott platformok keretében (Rab et al., 2015).

\section{SMART Village fogalmi lehatárolás}

Mindezen folyamatokkal párhuzamosan beindult a vidék népességmegtartó erejét szolgáló uniós "okos falu" (SMART Village) kísérleti projekt is az Európai Unióban és hazánkban egyaránt. Itt kell megemlíteni, hogy a SMART Village definíciója és jogszabályi háttere is még ,gyerekcipőben” jár a SMART City programmal összehasonlítva. Jelenleg a hazai SMART Village program a megvalósításában ott tart, hogy első lépésként a SMART Village pontos definíciót határozzák meg, valamint a jó gyakorlatokat és a gyakorlatban használható modelleket alakítják ki a programban résztvevők. Az elmúlt évek urbanizálódó tendenciáinak köszönhetően elmondható, hogy a hazai központi és meghatározó gazdasági szereppel 
rendelkező városok a gravitációs zónájukban elhelyezkedő falvakat a SMART kritériumok tekintetében is pozitív irányba mozdítják. Véleményünk szerint a hazai SMART City koncepciók keretében létrejövő kezdeményezések hatásai a központi várost körül ölelő kisebb, vidékies jellegü települések esetén is érezhető lesz a jövőben (Oláh et al., 2013). A jelenlegi tervek alapján az okos falvak koncepció keretében megközelítőleg egy millió euró jut majd tagországoként az előkészítő referenciapontok létrehozására, amely előzetes becslések alapján 2021-re alapozná meg az okos falvak koncepciót (www.hvg.hu). Továbbá hazánkban jelenleg még várat magára a SMART Village indikátorrendszer részletes kidolgozása is.

\section{SMART kezdeményezések elhelyezkedése Magyarországon}

A Lechner Tudásközpont online példatára segítségével összegyüjtésre került, hogy jelenleg (2017. november) 102 db SMART kezdeményezés érhető el hazánkban (3. ábra).

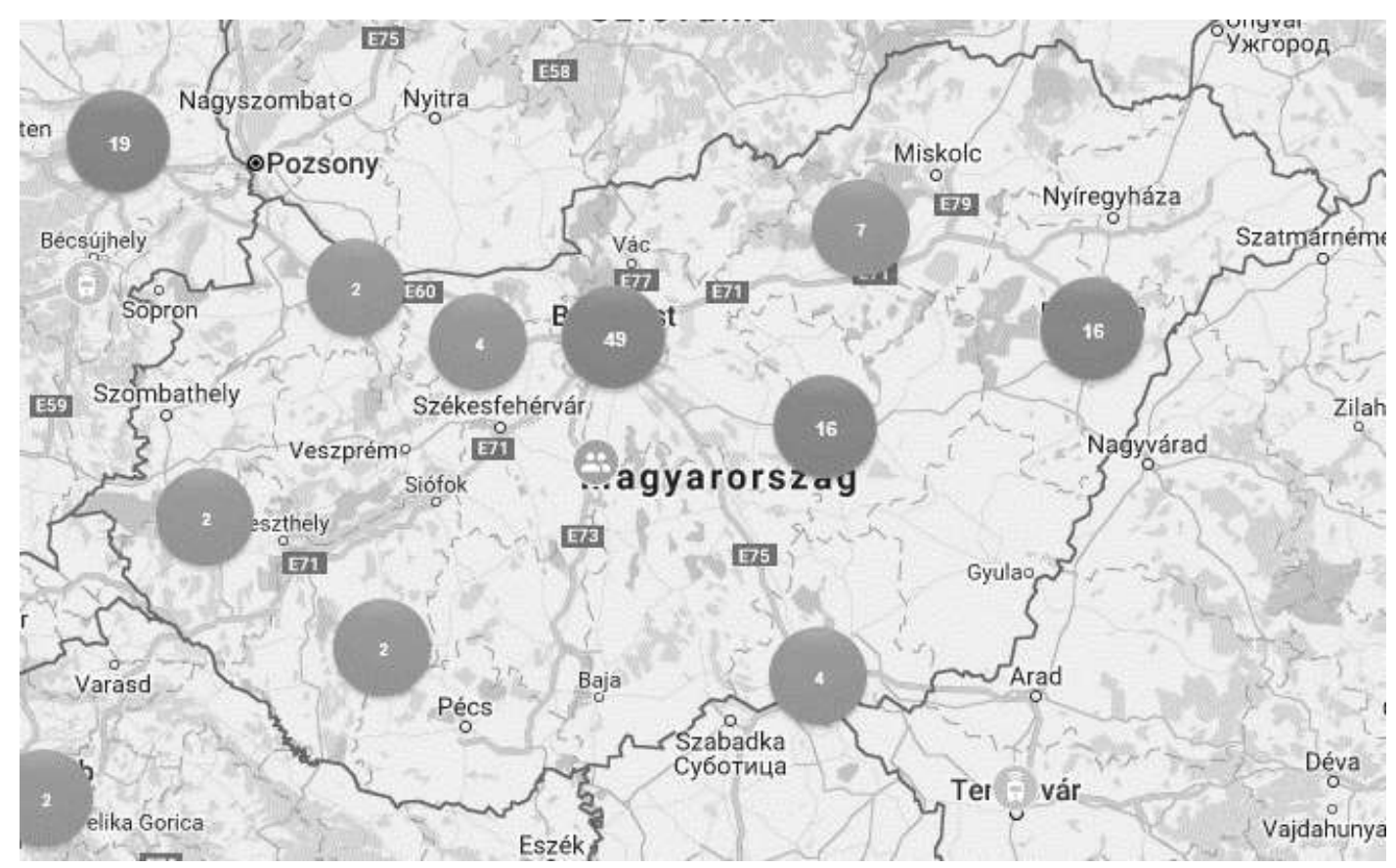

\section{3. ábra: Online okos kezdeményezések példatára 2017.}

Forrás: http://okosvaros.lechnerkozpont.hu/hu alapján saját szerkesztés, 2017.

A 3. ábra is jól alátámasztja Budapest centrális jellegét, hiszen a legtöbb, jelenleg $43 \mathrm{db}$ SMART kezdeményezés Pest-megyében és ebböl $49 \mathrm{db}$ pedig a fővárosban található. A Fővárosi Közgyülés 2017. januárban elfogadta a SMART City jövőképét. A dokumentumban javaslatot tesznek olyan gyakorlatokra, amik nyugati mintára okos várossá tehetik Budapestet. A stratégiai dokumentum kidolgozásában és elkészítésében is részt vettek a fejlesztésekben érdekelt fővárosi gazdasági társaságok, különböző civil szakértők, illetve az önkormányzat föosztályai. A jövőre vonatkozóan az alábbi szempontok figyelembe vételével indulnak a fejlesztések: a térségi tudásközpont létrehozása, fenntartható erőforrások, környezetvédelem, mobilitás, városi környezet, társadalmi partnerség, okos gazdaság (Lechner Tudásközpont).

\section{„Okos városok, okos városlakók”}

2017 szeptemberben került megrendezésre az első olyan konferencia hazánkban a Magyar Építéstechnika szervezésében, amely egy további rendezvénysorozat első információs-átadás meetingje volt Okos városok, okos városlakók címmel. A meghívott előadók a SMART City hazai és külföldi értelmezését, részterületeit, megvalósult és tervezés alatt álló fejlesztéseit mutatták be. A szervezők a félévenként tervezett folytatásban szakítani szeretnének a klasszikus konferencia-jellegü egyoldalú információ-átadással, és interaktív módon - smart eszközökkel 
- a hallgatóság bevonásával tárgyalják meg a SMART City koncepció egyes alrendszereinek elméleti és gyakorlati kérdéseit (http://magyarepitestechnika.hu). A rendezvénysorozatban az embert állítják középpontba és az okos várost az ember jobb életkörülményeinek megteremtéséhez, a környezeti-gazdasági- társadalmi fenntarthatóság biztosításához szükséges megoldások összességeként értelmezik. Véleményünk szerint a felhasználókat bevonva a tervezésbe, kivitelezésbe, tovább fejlesztésbe saját, valós igényeikhez alakított megoldások születhetnek. A Magyar Építéstechnika további célja, hogy e rendezvénysorozattal létrejöjjön egy platform, ahol az érdeklődők a tudás- és tapasztalatcserén kívül konkrét projekteket fejleszthetnek.

\section{Következtetések}

Összességében elmondható, hogy jelenleg még hazánkban teljes mértékü okos városok nincsenek, egyelöre több területfejlesztési szakember ,okosodó” városokról beszél Magyarországon. Elindultak a pozitív folyamatok az energetikai korszerüsítések, a közlekedési korszerüsítések (pl. intelligens zebra) terén, azonban általánosságban kijelenthető, hogy még a magyar városok messze állnak az ideálisnak vélt állapotoktól. A hazai megyei jogú városok többsége már felvette a kapcsolatot a Lechner Tudásközponttal és napjainkra elkezdődött a belső adottságokra épülő SMART City koncepciók kidolgozása. A SMART kezdeményezések száma folyamatosan nö, amelyet a fentiekben bemutatott online példatár nyomon követése is alátámaszt. Napjainkban még számos nyitott kérdés van a hazai városok okos várossá válásának folyamata kapcsán, azonban látszik, hogy elindult valami, amely okos és következetes tervezéssel, illetve az erőforrások hatékony beosztásával pozitív jövőbeli kilátásokat prognosztizálhat a SMART City koncepció kapcsán. Véleményünk szerint azonban nem lehet elégszer hangsúlyozni, hogy a SMART Village koncepció jelenleg még kiforratlan állapotban van hazánkban, azonban teljes mértékben egyet értünk azzal a ténnyel, hogy a vidék népességmegtartó erejének növelése fontos prioritásként kell, hogy szerepeljen Magyarország jövőjében.

\section{Összegzés}

Jelen tanulmányban a SMART City és SMART Village hazai fogalmi lehatárolását, illetve kialakulásának folyamatát gyüjtöttük össze a SMART kezdeményezések hazai alkalmazhatósága kapcsán. Hazánkban már több helyen találkozhatunk SMART City program keretében megvalósult projektekkel, illetve kezdeményezésekkel egyaránt. Összességében megállapítható, hogy a XXI. század kihívásaira felkészült, tudomány és innovatív technológiák iránt érdeklődő fiatal generáció kinevelése kulcsfontosságú a tudásalapú gazdasági fejlődése szempontjából. Fontosnak tartjuk, hogy a SMART City koncepció társadalmasítása folyamatos és pozitív fogadtatásra találjon a lakosok, érdeklődők részéről. A programokon való részvétel és az online követés is alátámaszthatja, hogy van igény erre a tevékenységre, az új eszközök, koncepciók megismertetésére a településeken. A tanulmány alapját egy 2017 szeptemberében elinduló kutatás adja, melybe a Szent István Egyetem gazdasági és vidékfejlesztési agrármérnök hallgatói közremüködésével végezzük a tevékenységeket. A jövőben célunk többek között Miskolc és Debrecen térségének áthatóbb tanulmányozása a SMART kezdeményezések és a Modern Városok Program tükrében. A területfejlesztési szakemberek többsége egyet ért azzal a ténnyel, hogy az okos városok fejlesztése nem egyszeri területfejlesztési program, hanem egy több éven átívelő folyamat, amely a gazdaság, a kormányzat, a tudományos és civil szervezetek együttes munkájával valósítható meg. Jelen tanulmány egy elméleti (leíró) tanulmány, amely alapját adja a további gyakorlati kutatásoknak, melynek részleteiről a későbbiekben szándékozunk publikálni. 


\title{
Köszönetnyilvánítás
}

\author{
争 \\ “AZ EMBERI ERÖFORRÁSOK MINISZTÉRIUMA ÚNKP-17-4 KÓDSZÁMÚ ÚJ NEMZETI \\ KIVÁLÓSÁG PROGRAMJÁNAK TÁMOGATÁSÁVAL KÉSZÜLT"
}

\section{Irodalom}

1. Batty M. et al. (2012): "Smart Cities of the Future". European Journal of Physics ST. 214: 481-518. doi:10.1140/epjst/e2012-01703-3

2. Dobos K. - Kulcsár S. - Nagy P. - Sik A. - Szemerey S. - Megyhárt É. (2015): SMART City Tudásplatform Metodikai javaslat, Lechner Tudásközpont, Budapest, 2015. http://lechnerkozpont.hu/doc/okos-varos/smart-city-tudasplatform-metodikai-javaslat.pdf

3. Kassai Zs. - Molnár M. (2016): The social success factors of local rural development In: Ritter K (szerk.) Economic and local aspects of rural development. 117 p. Gödöllö: Szent István Egyetemi Kiadó, 2016. pp. 108-117. ISBN:978-963-269-550-1

4. Káposzta J.- Ritter K. - Nagy H. (2016): Local Economic Development in Transition Economies: A Tool for Sustainable Development of Rural Areas In: Vasily Erokhin (szerk.) Global Perspectives on Trade Integration and Economies in Transition. $361 \mathrm{p}$. Hershey: IGI Global, 2016. pp. 281-298. ISBN:9781522504528

5. Lados M. (2011): Smart Cities tanulmány. [e-book] Győr: MTA RKK Nyugatmagyarországi Tudományos Intézet. http://www05.ibm.com/hu/download/IBM_SmarterCity_20110721.pdf, 20130109

6. McLaren - Duncan - Agyeman - Julian (2015): Sharing Cities: A Case for Truly Smart and Sustainable Cities. MIT Press. ISBN 9780262029728

7. Nagy A. - Sain M. - Sárdi A. - Vaszócsik V. (2015): Településértékelés és monitoring, módszertani javaslat, Lechner Tudásközpont, Budapest, 2015. http://lechnerkozpont.hu/doc/okos-varos/telepulesertekeles-es-monitornig-modszertani-javaslat.pdf

8. Oláh I.- Ritter K,.-Tóth T. (2013): The role of local communities in the disadvantaged rural areas In: Szendrő Katalin, Soós Mihály (szerk.) Proceedings of the 4th International Conference of Economic Sciences. 595 p. Konferencia helye, ideje: Kaposvár, Magyarország, 2013.05.09-2013.05.10. Kaposvár: Kaposvár University, 2013. pp. 547-553. (ISBN:978-963-9821-62-0)

9. Rab J. - Riedel M. - Steiner B. (2015): SMART City Példatár, Lechner Tudásközpont, Budapest, 2015. http://lechnerkozpont.hu/doc/okos-varos/smart-city-peldatar.pdf

10. Tóth T. - Káposzta J. (szerk.) (2014): Tervezési módszerek és eljárások a vidékfejlesztésben (elmélet) Gödöllő: Szent István Egyetemi Kiadó, 2014. 163 p. (ISBN:978-963-269-407-8)

11. Virág Á. (2017): A turisztikai együttmüködések hatékonysága a vidéki térségekben In: Ritter Krisztián (szerk.) Vidékgazdasági tanulmányok. 120 p. Gödöllö: Szent István Egyetemi Kiadó, 2017. pp. 43-54.

12. Vas Zs. - Bajmócy Z. (2012): Az innovációs rendszerek 25 éve. Szakirodalmi áttekintés az evolúciós közgazdaságtani megközelítésben. Közgazdasági Szemle, 59, 11, pp. 1233- 1256.

13. Biocon Tanácsadó Bt., IKT a városfejlesztésben ppt, 2016.

14. www.hvg.hu

15. http://kozigazgatas.netenahivatal.gov.hu

16. http://magyarepitestechnika.hu

17. http://okosvaros.lechnerkozpont.hu/hu

18. www.terport.hu 